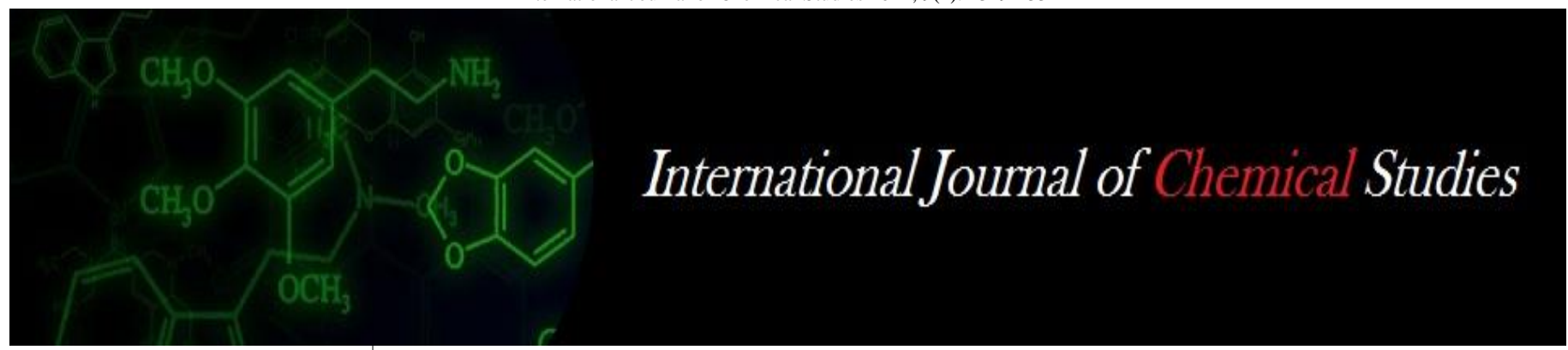

P-ISSN: 2349-8528

E-ISSN: 2321-4902

www.chemijournal.com

IJCS 2021; 9(1): 1329-1332

(C) 2021 IJCS

Received: 07-11-2020

Accepted: 16-12-2020

\section{VL Shinde}

Department of Horticulture, College of Agriculture, Dr. Balasaheb Sawant Konkan Krishi Vidyapeeth, Dapoli, Ratnagiri, Maharashtra, India

\section{Pawar}

Department of Horticulture, College of Agriculture, Dr. Balasaheb Sawant Konkan Krishi Vidyapeeth, Dapoli, Ratnagiri, Maharashtra, India

\section{OS Warang}

Department of Horticulture, College of Agriculture, Dr.

Balasheb Sawant Konkan Krishi Vidyapeeth, Dapoli, Ratnagiri,

Maharashtra, India

\section{Kulkarni}

Department of Horticulture, College of Agriculture, Dr.

Balasaheb Sawant Konkan

Krishi Vidyapeeth, Dapoli,

Ratnagiri, Maharashtra, India

\section{MS Joshi}

Department of Plant Pathology, College of Agriculture, Dr. Balasaheb Sawant Konkan Krishi Vidyapeeth, Dapoli, Ratnagiri, Maharashtra, India

Corresponding Author: OS Warang

Department of Horticulture, College of Agriculture, Dr. Balasheb Sawant Konkan Krishi Vidyapeeth, Dapoli, Ratnagiri, Maharashtra, India

\section{Studies on preparation of instant ready to serve (RTS) mix from jackfruit (Artocarpus heterophyllus)}

\author{
VL Shinde, CD Pawar, OS Warang, MM Kulkarni and MS Joshi
}

DOI: https://doi.org/10.22271/chemi.2021.v9.i1s.11407

\begin{abstract}
Jack fruit is one of the important tropical fruit crop belongs to family Moraceace. To avoid large postharvest losses in Jackfruit, it is necessary to do research on innovative processed products. The experiment of preparation of jackfruit instant RTS mix powder was conducted at Pomology laboratory, Fruit processing unit of Department of Horticulture, College of Agriculture, Dr. Balasaheb Sawant Konkan Krishi Vidyapeeth, Dapoli. The experiment was laid out in Completely Randomized Design with three treatments $\mathrm{T}_{1}(26.17 \%$ jackfruit powder $+72.57 \%$ sugar $+1.25 \%$ citric acid $), \mathrm{T}_{2}(31.78 \%$ jackfruit powder $+67.05 \%$ sugar $+1.17 \%$ citric acid $)$ and $\mathrm{T}_{3}(37.08 \%$ jackfruit powder $+61.84 \%$ sugar $+1.08 \%$ citric acid) with seven repetitions. Treatment $\mathrm{T}_{1}(26.17 \%$ jackfruit powder $+72.57 \%$ sugar $+1.25 \%$ citric acid) was found be best with respect to T.S.S., reducing sugars, titratable acidity, $\mathrm{pH}$ and ascorbic acid. Treatment $\mathrm{T}_{2}(31.78 \%$ jackfruit powder $+67.05 \%$ sugar $+1.17 \%$ citric acid) found best in sensory evaluation as it recorded maximum score for flavour and overall acceptability after 6 months storage period as well as recorded highest $\mathrm{B}: \mathrm{C}$ ratio.
\end{abstract}

Keywords: Preparation, ready, serve, RTS, Artocarpus heterophyllus

\section{Introduction}

The jackfruit (Artocarpus heterophyllus Lam.) is one of the important tropical fruits grown in the world and is believed to be native to India. In India, the major area under jackfruit is in Kerala state and it was regarded as heavenly fruit in the ancient periods. It is grown in an area of 156000 ha with annual production of 1826000 MT and productivity of 12 MT per ha (Anonymous, 2017) ${ }^{[1]}$.

Ripe jackfruit pulp is processed, dehydrated and sold as dry powder which is utilized for juice, biscuits, chutney, jam, jelly, toffee, paste, leather, bar, nectar, squash and pickle (Morton, $1965)^{[5]}$. The shelf life of fresh jackfruit fruits is limited. Therefore, it is important to use the fruit for the processing of various products in order to maximize its supply over an extended period and to maintain the price during the glut season. Ripe jackfruit bulbs are canned in syrup, either plain or blended with dehydrated bulbs, chutney, preserves, candy and concentrate and powder. Now a days, Consumer preferences have changed to diets with more natural antioxidants, dietary fibers, natural colourants, minerals, vitamins, reduced calories, low cholesterol and low sugar, free of chemicals, etc. Looking to the large postharvest losses in jackfruit, it is necessary to do research on innovative processed product from jackfruit. Hence, the experiment of preparation of jackfruit instant RTS mix powder was conducted.

\section{Material and Methods}

The experiment was conducted during the period May, 2018 to Jan, 2019. Study was conducted at Pomology laboratory, Fruit processing unit of Department of Horticulture, College of Agriculture, Dapoli and Fruit Beverage Research Centre of Dr. Balasaheb Sawant Konkan Krishi Vidyapeeth, Dapoli, District- Ratnagiri. The experiment was laid out in Completely Randomized Design with three treatments $\mathrm{T}_{1}(26.17 \%$ jackfruit powder $+72.57 \%$ sugar $+1.25 \%$ citric acid $), \mathrm{T}_{2}(31.78 \%$ jackfruit powder $+67.05 \%$ sugar $+1.17 \%$ citric acid $)$ and $\mathrm{T}_{3}(37.08 \%$ jackfruit powder $+61.84 \%$ sugar $+1.08 \%$ citric acid $)$ and seven replication. 
Fresh sound firm ripe jackfruits of kapa (Firm flesh) were selected for the preparation of jackfruit bulb powder. Fruits were washed with clean tap water and stored at ambient temperature for ripening. After ripening fruits were surface sterilized with 100 ppm chlorinated water for 5 minutes and then cut manually. The bulbs were scooped out manually and seeds were removed from the bulbs. The bulbs were cut into small pieces. These pieces were dipped in sugar solution of $70^{\circ} \mathrm{B}$ for $3 \mathrm{~h}$. These pieces were then dried in tray dryer at $60 \pm 2{ }^{\circ} \mathrm{C}$ for 27 hours. The dried bulbs were grounded in the pulverizer to make fine powder. This powder was sieved with $1 \mathrm{~mm}$ mesh sieve. Then as per the treatments fruit powder was mixed with sugar and citric acid. This well blended powder was packed into laminated aluminum foil and sealed well.

\section{Result and Discussion \\ Changes in chemical composition of jackfruit instant RTS mix during storage}

The data presented in Table 1 revealed that that T.S.S. was increased from zero month (80.90 0Brix) to 6 months $(89.34$ 0Brix) of storage, irrespective of treatments. During zero month storage, treatment $\mathrm{T}_{1} \quad(84.71$ 0Brix $)$ showed significantly maximum T.S.S. content which was at par with $\mathrm{T}_{2}$ (80.85 0Brix) and during 6 months storage treatment $\mathrm{T}_{1}$ (92.00 0Brix) showed significantly maximum T.S.S. content. Gradual increase in T.S.S. during storage may be due to hydrolysis of polysaccharides into monosaccharide and oligosaccharides. Similar finding was reported by Kotecha (2015) in powder prepared from papaya pulp. An increase in TSS content was reported in mango powder after 3 months of storage at ambient condition (Patil, 2011a) ${ }^{[6]}$. Treatment $T_{1}$ recorded maximum T.S.S. during storage. This might be due to addition of higher amount of sucrose in $\mathrm{T} 1(72.57 \%)$ as compared to other treatments, while preparing instant RTS mix.

Reducing sugars were decreased from ' 0 ' month $(9.50 \%)$ to 6 months $(7.62 \%)$ of storage, irrespective of treatments. During zero and six month storage, treatment $\mathrm{T}_{1}(10.69 \%$ and $8.95 \%)$ showed significantly maximum reducing sugar content. At high temperature, the condensation of reducing sugars with amino acids i.e. Maillard reaction is accelerated which is attributed to the increased loss of reducing sugars during storage (Thakur et al., 2000) ${ }^{[12]}$. Similar results were found by Swami et al. (2010) ${ }^{[11]}$ in kokum sarbat mix. Treatment $\mathrm{T}_{1}$ recorded maximum reducing sugars during storage. This might be due to addition of higher amount of sucrose in $\mathrm{T}_{1}$ $(72.57 \%)$ as compared to other treatments, while preparing instant RTS mix, which might be converted to reducing sugars.

Total sugars were increased from ' 0 ' month (58.83\%) to 6 month $(73.92 \%)$ of storage, irrespective of treatments. During zero and six months storage, treatment $\mathrm{T}_{3}(66.94 \%$ and $82.36 \%$ ) showed significantly maximum total sugar content. Gradual increase in total sugars might be due to Hydrolysis of starch into sugars as well as conversion of complex polysaccharides into simple sugars. Similar increase in sugars during storage has been reported by Swami et al. (2010) ${ }^{[11]}$ in ready mix powder of kokum sarbat mixes and Barooah (2018) [9] in spray dried ripe banana powder RTS. Treatment $\mathrm{T}_{3}$ recorded maximum total sugars during storage. This might be due to addition of higher amount of fruit powder (osmodehydrates) in $\mathrm{T}_{3}(37.08 \%)$ as compared to other treatments, while preparing instant RTS mix. However, the total sugars were showing decreasing trend from treatment $\mathrm{T}_{1}$ to $T_{3}$ because the sourness of citric acid is overtaking the sweetness of sugar.

Titratable acidity was decreased from 0 month (1.41\%) to 6 months $(1.00 \%)$ of storage, irrespective of treatments. During zero and six months storage, treatment $\mathrm{T}_{1}(1.71 \%$ and $1.09 \%)$ showed significantly maximum titratable acidity content. A slight decrease in acidity observed in present study was also reported in mango powder after 3 months storage at room temperature Dabhade and Khedkar (1980) ${ }^{[2]}$. Similar observation also reported in custard apple powder Patil (2011b) ${ }^{[7]}$. Decrease in acidity might be due to formation of polysaccharides and oxidation of reducing sugar by degradation of acids. Similar result reported by Wilson et al. (2014) ${ }^{[13]}$ in foam- mat dried mango powder. Treatment $T_{1}$ recorded maximum titratable acidity during storage. This might be due to addition of higher amount of citric acid in $\mathrm{T}_{1}$ $(1.25 \%)$ as compared to other treatments, while preparing instant RTS mix.

$\mathrm{pH}$ increased from ' 0 ' month (3.21) to 6 months (3.50) of storage, irrespective of treatments. During zero and six months storage, treatment $\mathrm{T}_{1}$ (3.01 and 3.37) showed minimum $\mathrm{pH}$. Increase in $\mathrm{pH}$ during storage may be attributed due to decrease in acidity during storage and can also be due to formation of sugars by degradation of acidic compounds. Similar results were obtained by Swami et al. (2016) ${ }^{[10]}$ in ripe jackfruit bulb powder.

Ascorbic acid decreased from ' 0 ' month $(0.70 \mathrm{mg} / 100 \mathrm{~g})$ to 6 months $(0.50 \mathrm{mg} / 100 \mathrm{~g})$ of storage, irrespective of treatments. During zero and six months storage, treatment $\mathrm{T}_{1}(0.86$ and $0.65 \mathrm{mg} / 100 \mathrm{~g}$ ) showed significantly maximum ascorbic acid content. Gradual decrease in ascorbic acid found in the present study may be due to the fact that ascorbic acid being sensitive to oxygen, light and heat was easily oxidized in presence of oxygen by both enzymatic and non- enzymatic catalyst. Similar decrease during storage has been reported by Rodge and yadlod (2009) ${ }^{[8]}$ in ber powder.

\section{Changes in sensory evaluation and microbial count of jackfruit instant RTS mix during storage}

The data presented in table 2 . Revealved that colour score decreased from ' 0 ' month (7.88) to 6 months (7.31) of storage, irrespective of treatments. At ' 0 ' and ' 6 ' months storage, highest colour score was recorded by treatment $\mathrm{T}_{3}$ (8.10 and 7.47) which was at par with $\mathrm{T}_{2}(8.02$ and 7.44). The change in color during storage was due to browning reaction between amino acid and reducing sugars, speed up by high temperature as reported by Swami et al. (2016) ${ }^{[10]}$ in ripe jackfruit bulb powder. Similar finding was reported by Kumar et al., (2012) ${ }^{[4]}$ in jackfruit powder.

Flavor and overall acceptability score decreased from ' 0 ' month (8.00 and 7.93) to 6 months (7.47 and 7.40) of storage, irrespective of treatments. At ' 0 ' and ' 6 ' months storage, highest flavour score was recorded by treatment $\mathrm{T}_{2}(8.31$ and 7.70) which was at par with $T_{3}(8.18$ and 7.61). At ' 0 ' and ' 6 ' months storage, highest overall acceptability score was recorded by treatment $\mathrm{T}_{2}(8.16$ and 7.60$)$ which was at par with $\mathrm{T}_{3}$ (8.14 and 7.54). Decrease in flavour of RTS prepared from instant RTS mix with increase in storage period may be due to decrease in aroma compounds and taste during storage. Similar finding was reported by Swami et al. (2016) ${ }^{[10]}$ in ripe jackfruit bulb powder and same also reported by Kumar et al., (2012) [4] in jackfruit powder. Decrease in overall acceptability score with increase in storage period may be due to slight oxidative browning and effect of temperature on aroma and taste of instant RTS mix. Similar finding was 
reported by Swami et al. (2016) ${ }^{[10]}$ in ripe jackfruit bulb powder.

Bacterial count was increased from ' 0 ' month $\left(0.00 \times 10^{6}\right)$ to 6 months $\left(1.23 \times 10^{6}\right)$ of storage period. During zero month storage, that is at initial stage there were no bacterial growth. At 6 month storage, the lowest bacterial count was found in treatment $T_{1}\left(1.00 \times 10^{6}\right)$ followed by $T_{2}\left(1.28 \times 10^{6}\right)$ and $T_{3}$ $\left(1.42 \times 10^{6}\right)$. The variation among treatments for bacterial count at 6 months storage was non-significant.

Fungal count was increased from ' 0 ' month $\left(0.00 \times 10^{6}\right)$ to 6 months $\left(1.09 \times 10^{6}\right)$ of storage period. During zero month storage, that is at initial stage there were no fungal growth. At 6 month storage, the lowest fungal count was found in treatment $T_{1}\left(1.00 \times 10^{6}\right)$ followed by $T_{2}\left(1.14 \times 10^{6}\right)$ and $T_{3}$ $\left(1.14 \times 10^{6}\right)$. While, the variation among treatments for fungal count at 6 months storage was non-significant.

\section{Production economics of jackfruit instant RTS mix}

Total expenditure for the production of jackfruit instant RTS mix was highest (Rs.1155.74) in $\mathrm{T}_{1}(26.17 \%$ jackfruit powder $+72.57 \%$ sugar $+1.25 \%$ citric acid) and lowest (Rs.1014.82) in $\mathrm{T}_{3}(37.08 \%$ jackfruit powder $+61.84 \%$ sugar $+1.08 \%$ citric acid).

Higher gross return and net profit of Rs. 2230 and Rs. 1154.28, respectively was found in $\mathrm{T}_{2}$ and lowest gross return and net profit of Rs. 1915 and Rs. 900.18, respectively was found in $T_{3}$. Benefit: cost ratio was maximum (2.08) in treatment $\mathrm{T}_{2}$.

Table 1: Changes in chemical composition of jackfruit instant RTS mix during storage

\begin{tabular}{|c|c|c|c|c|c|c|c|c|c|c|c|c|}
\hline \multirow{2}{*}{ Treatments } & \multicolumn{2}{|c|}{ TSS $\left({ }^{\circ}\right.$ Brix $)$} & \multicolumn{2}{|c|}{ Reducing sugars (\%) } & \multicolumn{2}{|c|}{ Total sugars (\%) } & \multicolumn{2}{|c|}{ Acidity (\%) } & \multicolumn{2}{|c|}{ pH } & \multicolumn{2}{|c|}{ Ascorbic acid (mg/100 gm) } \\
\hline & 0 montl & months & O months & 6 months & O month & months & montl & month & month & 6 months & O month & 6 months \\
\hline $\mathrm{T}_{1}$ & 84.71 & 92.00 & 10.69 & 8.95 & 50.89 & 87.85 & 1.71 & 1.09 & 3.01 & 3.37 & 0.86 & 0.65 \\
\hline $\mathrm{T}_{2}$ & 80.85 & 88.71 & 9.42 & 7.17 & 58.68 & 67.40 & 1.35 & 0.98 & 3.24 & 3.52 & 0.76 & 0.48 \\
\hline $\mathrm{T}_{3}$ & 77.14 & 87.85 & 8.41 & 6.74 & 66.94 & 82.36 & 1.19 & 0.93 & 3.39 & 3.62 & 0.50 & 0.37 \\
\hline Mean & 80.9 & 89.34 & 9.50 & 7.62 & 58.83 & 0.93 & 1.41 & 1.00 & 3.21 & 3.50 & 0.70 & 0.50 \\
\hline SE & 1.324 & 0.594 & 0.140 & 0.056 & 1.307 & 3.62 & 0.012 & 0.011 & 0.006 & 0.024 & 0.018 & 0.019 \\
\hline CD@1\% & 4.903 & 2.202 & 0.521 & 0.207 & 4.839 & 0.37 & 0.046 & 0.043 & 0.023 & 0.092 & 0.069 & 0.070 \\
\hline
\end{tabular}

Table 2: Changes in sensory evaluation and microbial count of jackfruit instant RTS mix during storage

\begin{tabular}{|c|c|c|c|c|c|c|c|c|c|c|}
\hline \multirow{2}{*}{ Treatments } & \multicolumn{2}{|c|}{ Colour } & \multicolumn{2}{c|}{ Flavour } & \multicolumn{2}{c|}{ Overall acceptability } & \multicolumn{2}{c|}{ Bacterial count } & \multicolumn{2}{c|}{ Fungal count } \\
\cline { 2 - 12 } & 0 month & 6 months & 0 months & 6 months & 0 month & 6 months & 0 month & 6 months & 0 month & 6 months \\
\hline $\mathrm{T}_{1}$ & 7.51 & 7.05 & 7.50 & 7.10 & 7.50 & 7.07 & 0.00 & 1.00 & 0.00 & 1 \\
\hline $\mathrm{T}_{2}$ & 8.02 & 7.44 & 8.31 & 7.70 & 8.16 & 7.60 & 0.00 & 1.28 & 0.00 & 1.14 \\
\hline $\mathrm{T}_{3}$ & 8.10 & 7.47 & 8.18 & 7.61 & 8.14 & 7.54 & 0.00 & 1.42 & 0.00 & 1.14 \\
\hline Mean & 7.88 & 7.31 & 8.00 & 7.47 & 7.93 & 7.40 & 0.00 & 1.23 & 0.00 & 1.09 \\
\hline SE & 0.115 & 0.066 & 0.062 & 0.037 & 0.088 & 0.033 & - & 0.308 & - & 0.306 \\
\hline CD @ 1\% & 0.428 & 0.245 & 0.232 & 0.139 & 0.324 & 0.191 & - & NS & - & NS \\
\hline
\end{tabular}

Table 3: Production economics of jackfruit instant RTS mix

\begin{tabular}{|c|c|c|c|c|}
\hline Treatments & $\begin{array}{c}\text { Total } \\
\text { Expenditure (Rs.) }\end{array}$ & $\begin{array}{c}\text { Gross } \\
\text { Returns (Rs.) }\end{array}$ & $\begin{array}{c}\text { Net Profit } \\
\text { (Rs.) }\end{array}$ & $\begin{array}{c}\text { B:C } \\
\text { Ratio }\end{array}$ \\
\hline $\mathrm{T}_{1}$ & 1155.74 & 2168 & 1012.26 & 1.87 \\
\hline $\mathrm{T}_{2}$ & 1075.75 & 2230 & 1154.28 & 2.08 \\
\hline $\mathrm{T}_{3}$ & 1014.82 & 1915 & 900.18 & 1.89 \\
\hline
\end{tabular}

\section{Conclusion}

From above results, we concluded that T.S.S., total sugars and $\mathrm{pH}$ of instant RTS mix were found to be increased whereas, reducing sugars, titratable acidity and ascorbic acid was decreased during storage of 6 months. Treatment $\mathrm{T}_{3}(37.08 \%$ jackfruit powder $+61.84 \%$ sugar $+1.08 \%$ citric acid) recorded maximum score for colour. Whereas, treatment $\mathrm{T}_{2}$ $(31.78 \%$ jackfruit powder $+67.05 \%$ sugar $+1.17 \%$ citric acid) recorded maximum score for flavour and overall acceptability after 6 month storage period. On the basis of sensory evaluation score, treatment $\mathrm{T}_{2}$ was found to be best.

\section{References}

1. Anonymous. Review committee meeting 2016-2017 of area and production of horticulture crops 2017.

2. Dabhade RS, Khedkar DM. Studies on drying and dehydration of raw mangoes for preparation of mango powder (amchur). Part IV. Drying and dehydration of mango pieces. Indian Food Packer 1980;34(3):39-42.

3. Kotecha P. Studies on preparation of powder from papaya pulp by using spray dryer. Doctoral dissertation, MPKV, University Library Rahuri 1980.
4. Kumar PV, Suneetha K, Sucharitha KV. Freeze drying-A novel processing for fruit powders. International Journal of Food and Nutritional Sciences 2012;1(1):16.

5. Morton JF. The Jackfruit (Artocarpus heterophyllus Lam.): Its Culture, Varieties and Utilization. In Proceedings of the Florida State Horticultural Society 1965;78:336-344.

6. Patil SB. Studies on preparation of powder from mango pulp by use of spray dryer. M.Sc. (Agri.) thesis. Mahatma Phule Agriculture University, Rahuri. (M.S.), India 2011a.

7. Patil TB. Standardization of a pretreatments for liquefaction of custard apple pulp for spray drying. M.Sc. (Agri.) thesis. Mahatma Phule Agriculture University, Rahuri. (M.S.), India 2011b.

8. Rodge BM, Yadlod SS. Storage studies of ber powder at room temperature. Asian Sciences 2009;4(1\&2):42-44.

9. Barooah N, Das P, Barooah MS, Seth DK, Dutta P. Storage Studies on Spray Dried Ripe Banana Powder Produced by Response Surface Methodology. Int. J Curr. Microbiol. App. Sci 2018;7(6):1922-1933.

10. Swami SB, Thakor NJ, Orpe S, Kalse SB. Development of ripe jackfruit bulb powder and its quality evaluation. $\mathrm{J}$ Food Res. Technol 2016;4(1):22-29.

11. Swami SB, Orpe S, Thakor NJ. Development of ready to prepare kokum sarbat mixes. Report of NAIP Projects, Dr. B.S. K. K. V. Dapoli 2010.

12. Thakur NK, Kaushal B, Joshi VK. Effect of different conditions of storage on physico-chemical and microbiological qualities of debittered kinnow juice 
concentrate. Journal of food science and technology (Mysore) 2000;37(4):415-418.

13. Wilson RA, Kadam DM, Chadha S, Grewal MK, Sharma M. Evaluation of Physical and Chemical Properties of Foam- Mat Dried Mango (Mangifera indica) Powder during Storage. Journal of Food Processing and Preservation 2014;38(4):1866-1874. 